\title{
REFORMASI BIROKRASI DESA PANGGUNGHARJO
}

\author{
Danang Septiyanto \\ Sekolah Tinggi Pembangunan Masyarakat Desa “APMD” Yogyakarta, Indonesia \\ Email: danangs1203@gmail.com
}

\begin{abstract}
ABSTRAK
Birokrasi memiliki peran yang penting dalam menjalankan roda pemerintahan di semua level pemerintahan termasuk pemerintahan desa. Akan tetapi, kualitas birokrasi khususnya di pemerintahan desa pada umumnya masih buruk. Berdasarkan kondisi tersebut, penelitian ini mengkaji upaya yang dilakukan oleh Pemerintah Desa Panggungharjo, Kecamatan Sewon, Kabupaten Bantul di bawah kepemimpinan Wahyudi Anggoro Hadi selaku kepala desa dalam melakukan Reformasi Birokrasi. Teknik pengumpulan data menggunakan ofebservasi, wawancara, studi kepustakaan dan dokumentasi. Metode analisis data penelitian ini adalah analisis deskriptif kualitatif. Hasil penelitian menunjukan bahwa Reformasi Birokrasi di Desa Panggungharjo bertujuan untuk mengembalikan kepercayaan warga masyarakat Desa Panggunghajo kepada Pemerintah Desa Panggungharjo mengingat birokrasi yang terkesan lamban, korup dan bias kepentingan elit. Untuk mewujudkan Reformasi Birokrasi tersebut maka berbagai upaya yang dilaksanakan yakni keteladanan, memperluas pelayanan publik dalam rangka mengubah relasi antara pemerintah desa dengan masyarakat, Pelayanan Administrasi Publik melalui Pelayanan Terpadu Satu Pintu, membangun kultur baru birokrasi dengan memberikan reward and punisment, keterbukaan informasi publik serta mengingkatkan kualitas Sumber Daya Manusia (SDM) perangkat desa. Reformasi Birokrasi berimplikasi pada peningkatan kinerja Pemerintah Desa Panggungharjo sehingga Pemerintah Desa Panggungharjo mendapatkan banyak penghargaan baik dari dalam maupun luar negeri.
\end{abstract}

Kata Kunci: Reformasi Birokrasi; Pemerintah Desa; Panggungharjo.

\begin{abstract}
Bureaucracy has an important role in running the government at all levels of government. However, the quality of the bureaucracy, especially in village government, is generally still poor. Based on these conditions, this study examines the efforts made by the Panggungharjo Village Government, Sewon District, Bantul Regency under the leadership of Wahyudi Anggoro Hadi as the village head in carrying out Bureaucratic Reform. Data collection techniques using observation, interviews, literature study and documentation. The data analysis method of this research is descriptive qualitative analysis. The results show that the Bureaucratic Reform in Panggungharjo Village aims to restore the trust of the people of Panggunghajo Village to the Panggungharjo Village Government considering the bureaucracy that seems slow, corrupt and biased by elite interests. To realize the Bureaucratic Reform, various efforts were carried out, namely exemplary, expanding public services in order to change the relationship between the village government and the community, Public Administration Services through One Stop Services, building a new culture of bureaucracy by providing rewards and punishments, openness of public information and increasing quality of Human Resources (HR) of village officials. Bureaucratic reform has implications for improving the performance of the Panggungharjo Village Government so that the Panggungharjo Village Government has received many awards both from within and outside the country.
\end{abstract}


Keywords: Bureaucratic Reform; Village Government; Panggungharjo.

\section{Informasi Artikel}

Diterima: Oktober 2021, Disetujui: November 2021, Dipublikasikan: Desember 2021

DOI: https://doi.org/10.47431/governabilitas.v2i2.110

\section{PENDAHULUAN}

Keberadaan Birokrasi sangatlah penting bagi jalannya roda pemerintahan, tidak terkecuali bagi pemerintahan di tingkat desa. Namun pada kenyataannya masih banyak kinerja birokrasi di tingkat pemerintahan desa yang belum sesuai yang diharapkan. Misalnya, etos kerja yang rendah yang ditandai dengan kehadiran yang rendah serta belum adanya pengaturan jam kerja. Kondisi ini diperburuk dengan kondisi kualitas Sumber Daya Manusia (SDM) yang juga kurang mumpuni, baik dalam pemahaman regulasi terkait penyelenggaraan pemerintahan desa maupun penggunaan teknologi dalam menunjang kelancaran pekerjaan. Dengan kondisi birokrasi yang problematik tersebut menjadikan gerak langkah birokrasi menjadi lamban. Apabila kinerja birokrasi seperti gambaran tersebut tidak diubah maka pemerintah desa tidak mungkin dapat menjalankan tugas dan fungsinya dengan baik sesuai dengan amanah regulasi dan juga harapan untuk menciptakan kesejahteraan masyarakat desa.

Keberadaan birokrasi dalam sebuah organisasi sangatlah penting karena birokrasi dirancang untuk menghasilkan tindakan yang rasional. Disadari bahwa birokrasi alat untuk menjalankan berbagai kebijakan yang diambil oleh pemerintah, namun masalahnya adalah bagaimana melakukan pengawasan terhadap birokrasi tersebut (Sinambela, 2016:53). Sedangkan menurut Albrow (1989:116-117), birokrasi dimaknai sebagai pemerintahan yang dijalankan oleh badan eksekutif pemerintah serta pejabat publik baik yang menduduki jabatan tinggi maupun rendah.

Birokrasi di Indonesia pada umumnya masih menunjukan kinerja yang buruk khususnya yang berhubungan dengan pelayanan publik serta memiliki jenjang prosedur yang panjang. Oleh karena itu, tidak mengherankan bila persepsi masyarakat terhadap birokrasi menjadi negatif. Dalam rangka mewujudkan pemerintahan yang baik (good governance) maka reformasi birokrasi merupakan langkah yang penting untuk mewujudkan aparatur negara yang kompeten. Reformasi Birokrasi dalam konteks ini merupakan perubahan yang dilaksanakan secara bertahap bukan perubahan secara cepat dan drastis atau radikal. Perubahan ini mencakup perbaikan struktur dan palayanan kepada 
masyarakat serta pola pikir serta budaya para pegawai (Pamungkas dkk, 2019).

Pada umumnya, aspek-aspek yang menjadi sasaran reformasi birokrasi yakni kelembagaan (organisasi), ketatalaksanaan, dan sumber daya manusia aparatur (Thahir, 2015:151). Hal tersebut menjadi wajar mengingat pada aspek-aspek tersebut birokrasi pada umumnya menunjukan titik lemahnya. Reformasi birokrasi menurut Sedarmayanti (2013: 71-72), merupakan upaya yang dilakukan oleh pemerintah untuk meningkatkan kinerja melalui berbagai cara untuk mencapai efektifitas, efisien, dan akuntabel.

Sedangkan Mustafa (2014:153), berbendapat bahwa reformasi birokrasi bertujuan untuk merebut kembali rasa kepercayaan masyarakat kepada birokrasi. Hal ini dapat dipahami mengingat birokrasi masih memiliki kesan yang buruk yakni lamban, korup dan bias kepentingan elit. Kondisi birokrasi di desa juga memiliki potret yang tidak jauh berbeda. Oleh karena itu, maka upaya reformasi birokrasi di tingkat pemerintah desa juga memiliki tantangan yang tak kalah peliknya.

\section{METODE PENELITIAN}

Penelitian ini menggunakan pendekatan deskriptif kualitatif dengan lokasi penelitian di Desa Panggungharjo, Kecamatan Sewon, Kabupaten Bantul. Sumber data yang digunakan dalam penelitian ini adalah sumber data primer dan sumber data sekunder. Pengumpulan data primer dilakukan melalui penelitian lapangan secara langsung ke lapangan untuk menemukan fakta-fakta yang terjadi di lokasi penelitian. Tujuan penelitian lapangan (field research) adalah untuk mendapatkan data dan informasi yang berkaitan dengan masalah yang diteliti (Soemitro, 1998: 92). Pengumpulan data sekunder dilakukan melalui penelitian kepustakaan dan dokumentasi. Dalam penelitian ini, teknik pengumpulan data yang digunakan yakni:

a. Teknik pengumpulan data primer dilakukan dengan observasi dan wawancara secara langsung di lapangan dengan informan atau subjek penelitian.

b. Teknik pengumpulan data sekunder dilakukan dengan studi kepustakaan dan dokumentasi (library and documentation). Studi kepustakaaan dilakukan dengan cara membaca, memahami serta mengkaji berbagai sumber data sekunder yang relevan dengan permasalahan penelitian yang diteliti.

Adapun yang dijadikan subjek penelitiaan atau informan dalam penelitian ini, terdiri dari unsur:

a. Kepala Desa Panggungharjo.

b. Perangkat Desa Panggungharjo. 
c. Badan Permusyawaratan Desa Pangungharjo.

d. Warga Desa Panggungharjo.

Pemilihan subjek penelitian atau informan dari unsur-unsur tersebut dimaksudkan agar kajian Reformasi Birokrasi di Desa Panggungharjo memiliki data yang komprehensif.

\section{HASIL PENELITIAN}

Citra buruk yang masih melekat pada birokrasi pemerintah desa harus dihilangkan. Citra yang melekat ini tidak semata-mata kesalahan aparatur pemerintah desa. Menurut pendapat Wahyudi Anggoro Hadi (2020 : 50), Kepala Desa Panggunharjo, ada beberapa penyebab yang menjadikan keterpurukan desa. Pertama, desa tidak pernah diurus oleh negara dan tidak pernah dipandang sebagai entitas politik sejak terbitnya Undang-Undang Desa Nomor 5 Tahun 1979. Sebagai akibatnya maka perangkat desa tidak memiliki kemampuan yang handal dalam memberikan pelayanan publik karena tidak pernah dilatih untuk meningkatkan kapasitasnya. Penyebab kedua, karena dalam sistem pemerintahan desa tidak dikenal jenjang karier maka perangkat desa tidak memiliki kepentingan untuk meningkatkan kinerjanya dalam rangka untuk menapaki jenjang karier.

Kepala desa sebagai kepala pemerintahan di desa tentu memiliki peran yang penting dalam penyelenggaraan pemerintahan desa termasuk dalam melakukan reformasi birokrasi. Kepala desa memiliki kepentingan agar birokrasinya dapat bekerja dengan profesional sehingga program kerjanya dapat berjalan dengan baik. Selain itu, ia juga menjadi pengambil keputusan dalam setiap kebijakan dan program di tingkat desa serta menjadi bagian utama dari kelas elit di desa. Dengan demikian maka kepemimpinan Kepala Desa memiliki determinasi yang kuat bagi berhasil atau tidaknya pembangunan di desa. Kepemimpinan kepala desa akan menentukan apakah pembangunan akan berhasil atau tidak (Saefulrahman, 2015). Terkait dengan kepemimpinan, Hasyim (2016) berpendapat bahwa kepemimpinan merupakan instrumen yang digunakan oleh seseorang untuk menggerakan orang lain sesuai dengan tujuan yang dikendaki.

\section{Peran Kepala Desa dalam Melakukan Reformasi Birokrasi}

Membenahi birokrasi yang sudah lama bekerja memiliki kultur yang buruk bukanlah pekerjaan mudah. Untuk membenahi birokrasi di Desa Panggungharjo, Wahyudi Anggoro Hadi selaku Kepala Desa Panggungharjo melakukan hal-hal sebagai berikut: 


\section{a. Keteladanan}

Untuk membuat perubahan birokrasi Wahyudi Anggoro hadi tidak hanya sekedar berbicara namun memberikan contoh keteladanan mulai dari hal-hal yang kecil namun mendasar. Misalnya, dengan berangkat lebih pagi dari pada perangkat yang lain. Selain itu, juga tidak segan-segan untuk membersihkan WC yang terlihat kotor. Demikian pila ketika pulang kantor, maka sebelum pada waktunya pulang, pantang baginya untuk pulang ke rumah. Hal tersebut pada akhirnya membuat sungkan para perangkat desa yang lain, yang pada umumnya masih berangkat ke kantor siang hari dan pulang ke kantor ketika waktu dzuhur, sehingga pelan-pelan ada beberapa perangkat desa yang mengikuti jejaknya. Bagi Wahyudi Anggoro Hadi, seorang pemimpin harus dapat memberikan keteladanan. Keteladanan pemimpin adalah hal yang utama sebelum meraih suatu tujuan atau menghadapi suatu rintangan (Novidwyanto, 2021).

"Pada masa awal kepemimpinan ketika pamong kurang perhatian pada masalah kebersihan pak lurah tidak segan segan untuk membersihkan. Atau membuka kantor sendiri karena pamong dulu terpola mangkat awan bali awan. Begitu pula ketika belum jam pulang kantor Pak Lurah belum pulang dan ketika pamong sudah pulang sebelum jam kerja maka pak lurah pun menutup kantor sendiri. Pak lurah berangkat paling awal pulang paling akhir sesuai dengan jam kerja. Sehingga bawahannya lambat laun menjadi risih dan kemudian terdorong untuk berangkat sesuai dengan jam kerja." (wawancara dengan Sunardiyono, S.Pd, Pangripto (Kaur Perencanaan) Desa Panggungharjo, 28 Juli 2021).

Perilaku keteladanan pemimpin dilakukan dengan menunjukan kepada para bawahan mengenai apa yang harus mereka lakukan, memberikan contoh, memberi tahu apa yang diharapkan dari mereka. Hal tersebut dapat dapat ditunjukan melalui disiplin waktu, kepatuhan terhadap aturan, prosedur, tugas dan tanggungjawab (Hasyim, 2016).

\section{b. Memperluas Pelayanan Publik Dalam Rangka Mengubah Relasi antara Pemerintah Desa dengan masyarakat.}

Kualitas pelayanan publik di Indonesia belum menunjukan hal yang menggembirakan. Tingkat kepuasan masyarakat terhadap pelayanan publik masuh rendah. Hal ini disebabkan karena masih terdapat perlakuan yang berbeda dalam mendapatkan pelayanan publik yang dipengaruhi oleh pertimbangan-pertimbangan yang tidak objektif. Selain itu, ketidakpastian standar biaya menyebabkan munculnya KKN, supaya pengguna jasa mendapatkan kepastian dan kualitas pelayanan (Kusmayadi dan Nurohman, 2011).

Dalam konteks Reformasi Birokrasi Desa Panggungharjo, Wahyudi Anggoro Hadi 
melakukan perluasan pelayanan publik dari yang hanya sebatas pelayanan publik administratif diperluas menjadi pelayanan barang dan jasa publik, dengan demikian masyarakat tidak hanya menerima manfaat dari pelayanan tersebut namun dapat terbangun kedekatan antara warga dan pemerintahan desa.

"Ketika kita berbicara tentang reformasi birokrasi yang paling substantif sebenarnya merubah pola relasi antara pemerintah desa warga desa. Jadi yang paling substantif dari reformasi birokrasi bukan analisi jabatan, memberikan tambahn penghasilan berupa tunjangan kinerja. Mengapa ini penting? Karena relasi antara pemerintah desa dan warga yang terjadi selama ini hanya relasi administratif misalnya mengurus KTP, sertifikat tanah atau surat izin menikah. Oleh karena itu, pola relasi tersebut harus diubah dengan cara memperluas dimensi pelayanan publik, tidak hanya sebatas pelayanan administrasi publik tapi juga pelayanan yang berkaitan dengan barang dan jasa publik. Misalnya ketika anak tidak bisa bersekolah, tidak adanya pelayanan kesehatan yang memadai bagi ibu hamil, limbah sampah yang tidak terurus dengan baik maka hal itu menjadi urusan pemerintah desa untuk hadir dan menyelesaikan. (wawancara dengan Wahyudi Anggoro Hadi, Kepala Desa Panggungharjo, 14 Agustus 2021).

Dalam rangka memperluas dimensi pelayanan publik dalam bidang pelayanan barang dan jasa publik, maka Pemerintah Desa Panggungharjo membentuk lembagalembaga desa, antara lain sebagai berikut:

\section{1) Badan Usaha Milik Desa (BUM Desa)}

Desa Panggungharjo membentuk Badan Usaha Milik Desa (BUM Desa) sejak tahun 2013 dengan nama BUM Desa Panggung Lestari. Salah satu unit usaha BUM Desa Panggung Lestari adalah pengelolaan sampah, hal ini untuk mengatasi permasalahan sampah yang ada ditengah masyarakat. Desa Panggungharjo yang secara geografis terletak di area suburban dengan penduduk berjumlah 28.141 jiwa (data kependudukan Dukcapil Kabupaten Bantul Tahun 2018) tentu memiliki kendala dalam pengelolaan sampah. Oleh karena itu maka BUM Desa hadir untuk mengatasi permasalahan tersebut. Keberadaan unit usaha pengelolaan sampah menjadi sarana untuk menjaga kebersihan lingkungan yang bermanfaat bagi warga Desa Panggungharjo. Dengan demikian, eksis negatif dari volume sampah yang berlebihan dapat dihindarkan.

\section{2) Badan Pelaksana Jaring Pengaman Sosial (Bapel JPS)}

Untuk mewujudkan pelayanan sosial kepada warga masyarakat Desa Panggungharjo maka pada tahun 2013, Pemerintah Desa Panggungharjo membentuk Badan Pelaksana Jaring Pengaman Sosial (Bapel JPS). Pembentukan lembaga ini 
bertujuan untuk memberikan perlindungan sosial kepada warga masyarakat di Desa Panggungharjo yang kurang mampu. Adapun pembiaayan untuk kegiatan ini bersumber dari pemerintah desa atau masyarakat.

"Bapel JPS merupakan upaya untuk memberikan perlindungan pada warga desa yang mengalami kerentanan dalam bidang pendidikan, kesehatan dan ketahanan pangan melalui beberapa skema. Bidang pendidikan kita ada beasiswa pendidikan, bantuan pendidikan tunai, kerjasama dengan perguruan tinggi, untuk anak-anak kita sekolah disana sampai lulus dengan gratis dsb. Dan itu sampai hari ini masih berjalan. Perlindungan kesehatan kita punya perlindungan kesehatan ibu dan anak. Seorang ibu hamil berhak atas layanan paripurna, 7 kali pemerikasaan kehamilan, satu kali persalinan normal, 2 kali pemeriksaan nifas dan 5 imunisasi lengkap. Bapel JPS kita dirikan sebagai jaring pengaman sosial terakhir. Karena data yang digunakan dari Kementerian Sosial pada waktu itu berangkat dari data yang amburadul. Sehingga memungkinkan warga yang sebenarnya dapat perlindungan dari negara tidak memperoleh perlindungan yang layak. Jadi ada Jamkesmas ada Jamkesda tapi baik jamkesmas maupun jamkesda tapi berangkat dari sistem data yang amburadul. Ketika ada warga desa yang tidak memperoleh Jamkesmas dan Jamkesda maka pemerintah desa yang seharusnya memberikan jamin pengaman sosial terkahir. Sehingga warga desa yang merasa berhak mendapatkan jaminan sosial dari desa melakukan pengaduan atau usulan/permohonan kepada pemerintah desa untuk mendapatkan palayanan jaminan sosial. Pendampingan kepada lansia juga masih dilaksanakan hingga saat ini. Ada empat puluhan lansia yang tiap minggu dikunjungi oleh perawat desa untuk memastikan mereka berada di hunian yang layak, memperoleh asupan pangan yang cukup serta pada kondisi kesehatan yang termonitor". (wawancara dengan Wahyudi Anggoro Hadi, Kepala Desa Panggungharjo, 14 Agustus 2021)

\section{3) Lembaga Mediasi Desa (LMD)}

Sejak tahun 2015, untuk membantu warga masyarakat menyelesaikan permasalahan hukum maka Pemerintah Desa Panggungharjo membentuk Lembaga Mediasi Desa (LMD). Pendekatan hukum yang digunakan menggunakan jalun non litigasi (di luar pengadilan). Hal ini dilakukan untuk menjaga hubungan baik antar warga yang memiliki permasalahan hukum. Di lingkup desa, permasalahan hukum yang kerap dijumpai yakni terkait sengketa lahan maupun waris yang biasanya melibatkan kekerabatan yang dekat.

"Permasalahan-permasalahan hukum yang melingkupi warga desa tidak jauh-jauh dari sengketa lahan. Rebutan pathok rebutan kikis gitu kan..tidak jauh jauh dari sengketa waris yang biasanya melibatkan orang-orang dengan tingkat kekerabatan yang dekat. Sengketa lahan itu adanya antar tetangga, sengketa waris antar ahli waris. Nah kalau penyelesaian hukum itu melalui jalur litigasi atau jalur pengadilan bisa dipastikan kekerabatan mereka mesti rusak." (wawancara dengan Wahyudi Anggoro Hadi, Kepala Desa Panggungharjo, 14 Agustus 2021) 


\section{4) Panggung Tanggap Covid-19}

Pemerintah Desa panggungharjo tentu tidak menutup mata terhadap bencana yang menimpa secara global saat ini. Bencana Covid-19 tentu juga dirasakan dampaknya oleh warga desa Panggungharjo. Sebagai perwujudan pelayanan publik kepada masyarakat desa Panggungharjo, Pemerintah Desa Panggungharjo melakukan berbagai upaya untuk menanggulangi pandemi tersebut.

Pemerintah Desa Panggungharjo melakukan respon cepat dengan membentuk gugus tugas dalam rangka penanganan pandemi dengan nama Panggung Tanggap Covid-19 (PTC-19). Pembentukan gugus tugas tersebut dilakukan kurang dari tiga minggu sejak kasus Covid-19 pertama di Indonesia diumumkan. Gugus tugas ini tidak hanya bergerak dalam rangka pengurangan dampak kesehatan, tetapi juga untuk menangani dampak sosial maupun ekonomi yang dialami oleh warga Desa Panggungharjo.

Selain membentuk gugus tugas Panggung Tanggap Covid-19 (PTC-19), Pemerintah Desa Panggungharjo membuat platform e-commerce berbasis web dengan nama pasardesa.id. Pasardesa.id adalah platform digital berbasis android yang digunakan sebagai perantara antara toko atau warung dengan para pembeli. Pasardesa.id merupakan respon terhadap pandemic Covid-19 dimana penjualan produk dagang dari toko atau warung di Desa Panggungharjo menjadi terhambat karena pandemi tersebut sehingga dengan Pasardesa.id menjadi sarana agar usaha toko atau warung di Desa Panggungharjo bisa berjalan dengan lancar.

Selanjutnya untuk memitigasi dampak kesehatan akibat Covid-19, Pemerintah Desa Pangunghajo menginisiasi aplikasi Bantultangguh.com. "Bantultangguh.com memberikan informasi terkait yang terkonfirmasi positif, yang kontak erat maupun yang suspek dengan derajat gejala berat, sedang ringan atau OTG (Orang Tanpa Gejala). Yang bergejala berat dan sedang kita masukan dalam sistem daftar antrian rumah sakit sedangkan yang bergela ringan dan OTG dilakukan analisis non klinis untuk menentukan apakah isolasi di rumah atau di shelter. Bantul tangguh juga digunakan untuk mitigasi kedaruratan. Ketika ada perubahan derajat kedaruratan dari yang bergejala sedang dan berat maka kita akan lakukan koordinasi, kita rujuk ke rumah sakit dsb. Sehingga meskipun kasus covid di Panggungharjo sangat banyak yakni 2.434 penduduk yang terkonfirmasi posistif tapi kematiannya paling kecil yakni 85 penduduk. Karena mitigasi kedarutannya berjalan." (wawancara dengan Wahyudi Anggoro Hadi, Kepala Desa Panggungharjo, 14 Agustus 2021). 


\section{5) Pelayanan Administrasi Publik melalui Pelayanan Terpadu Satu Pintu}

Selain melakukan perluasan dimensi pelayanan publik, tidak lupa Pemerintah Panggungharjo juga memperbaiki pelayanan administrasi publik melalui Pelayanan Terpadu Satu Pintu. Melalui pelayanan ini, untuk mengurus pelayanan administratif, masyarakat cukup melalui satu ruangan yang telah disediakan. Pemerintah Desa Panggungharjo membenahi ruang pelayanan administrtif satu pintu menjadi ruangan yang sangat nyaman. Ruangan tersebut cukup representatif yang dilengkapi dengan pendingin udara, deretan kursi yang nyaman untuk warga yang menunggu pelayanan, serta bersih. Kemudian ada pengumuman yang menyatakan bahwa segala bentuk pelayanan publik tidak dipungut biaya.

Ruang pelayanan bagi masuknya perangkat desa hanya ada satu pintu, sehingga arus masuk-keluarnya perangkat desa akan terlihat dengan jelas. Hal demikian dimaksudkan untuk mencegah perangkat desa pulang sebelum waktu kerja berakhir. Untuk memberikan pelayanan yang optimal kepada masyarakat terkait pelayanan administratif maka Pemerintah Kalurahan Panggungharjo menerbitkan Peraturan Lurah Nomor 9 Tahun 2021 tentang Standar Pelayanan Minimal Kalurahan Panggungharjo. Dalam regulasi ini diatur terkait mekanisme serta waktu yang dibutuhkan untuk mengurus pelayanan adminstratif.

\section{c. Membangun Kultur Baru Birokrasi dengan memberikan Reward and Punishment}

Langkah berikutnya yang dilakukan dalam rangka reformasi birokrasi di Desa Panggungharjo adalah membangun kultur baru birokrasi. Sehingga pada tahun 2016 dilakukan penilaian kinerja dengan cara melakukan analisis jabatan, analisis beban kerja, sehingga mengasilkan rumusan tambahan pengasilan berbasis kinerja. Rumusan tersebut menghasilkan kebijakan tambahan penghasilan bagi aparatur Pemerintah Desa Panggungharjo. Selain itu, kebijakan ini merupakan instrumen untuk memberikan penghargaan (reward) dan hukuman (punishment) bagi aparatur Pemerintah Desa Panggungharjo.

Pengaturan mengenai tambahan penghasilan ini diatur melalui Peraturan Desa Panggungharjo Nomor 01 Tahun 2016 tentang Pemberian Tambahan Penghasilan bagi Aparatur Pemerintah Desa. Adapun tujuan dari pemberian tambahan penghasilan ini, menurut konsideran regulasi tersebut adalah untuk meningkatkan kinerja Pamong Desa Panggungharjo. Dengan adanya regulasi tersebut maka kepala desa dan perangkat desa diharapkan dapat meningkatkan disiplin yang berdampak pada peningkatan pelayanan 
terhadap masyarakat. Adapun besaran tambahan penghasilan bagi Kepala Desa dan Perangkat Desa pada tahun 2016 yaitu:

1. Kepala Desa mendapat tambahan penghasilan per bulan sebesar Rp. 818.000,00 (delapan ratus delapan belas ribu rupiah).

2. Sekretaris Desa mendapat tambahan penghasilan per bulan sebesar Rp. 752.000,00 (tujuh ratus lima puluh dua ribu rupiah).

3. Kasi Pembangunan mendapat tambahan penghasilan per bulan sebesar Rp. 723.000,00 (tujuh ratus dua pulih tiga ribu rupiah).

4. Kasi Pemerintahan mendapat tambahan penghasilan per bulan sebesar Rp. 586.000,00 (lima ratus delapan puluh enam ribu rupiah).

5. Kaur Program mendapat tambahan penghasilan per bulan sebesar Rp. 701.000,00 (tujuh ratus satu ribu rupiah).

6. Kaur Umum mendapat tambahan penghasilan per bulan sebesar Rp. 538.000,00 (lima ratus tiga puluh delapan ribu rupiah).

7. Dukuh mendapat tambahan penghasilan per bulan sebesar Rp. 467.000,00 (empat ratus enam puluh tujuh ribu rupiah).

8. Staf Senior I mendapat tambahan penghasilan per bulan sebesar Rp. 534.000,00 (lima ratus tiga puluh empat ribu rupiah).

9. Staf Senior II mendapat tambahan penghasilan per bulan sebesar Rp. 497.000,00 (empat ratus sembilan puluh tujuh ribu rupiah).

Namun, tambahan penghasilan tersebut tidak dapat diberikan secara penuh bila Kepala Desa dan Perangkat Desa melakukan hal-hal sebagai berikut:

1. Terlambat masuk kerja tanpa keterangan yang sah, dipotong $2 \%$ (dua persen) perhari.

2. Pulang mendahului tanpa keterangan yang sah, dipotong $2 \%$ (dua persen) perhari.

3. Tidak masuk kerja tanpa keterangan yang sah dipotong 4\% (empat persen) perhari.

4. Ijin tidak masuk kerja lebih dari 2 (dua) kali dalam 1 (satu) bulan dipotong $4 \%$ (empat persen) sesuai dengan jumlah kelebihan hari.

Hingga saat ini, Tambahan Penghasilan bagi Kepala Desa dan Perangkat Desa Panggungharjo masih dilaksanakan. Regulasi terbaru yang mengatur hal tersebut adalah Peraturan Kalurahan Panggungharjo Nomor 4 Tahun 2021 tentang Tunjangan Kinerja Bagi Lurah, Pamong Kalurahan, Staf Kalurahan dan Badan Permusyawaratan Kalurahan 
Panggungharjo, Kapanewon Sewon, Kabupaten Bantul. Selain itu, sejak tahun 2016 perangkat desa yang berkinerja terbaik setiap 3 bulan dimuat dalam warta dedikasi dan ditempel di ruang pelayanan. Tujuannya agar masyarakat mengetahui perangkat desa yang berkinerja terbaik dalam 3 bulan terakhir. Dengan kriteria berdasarkan pengukuran kinerja dengan dua komponen yakni pemenuhan jam kerja dan pemenuhan capain kinerja. Warta Dedikasi tersebut merupakan sebuah upaya untuk mendorong terjadinya perubahan perilaku khususnya terkait dengan kultur birokrasi Pemerintah Desa Panggungharjo sehingga menjadi bagian dari insentif kepada perangkat desa yang dinilai mempunyai kinerja terbaik dalam tiga bulan. Penyerahan Warta Dedikasi dilaksanakan setelah pelaksanaan apel yang diselenggarakan pada hari Senin. Selain itu, perangkat desa berkinerja terbaik tersebut juga mendapat apresiasi berupa uang sebesar Rp. 600.000,00.

"Tiap tiga bulan sekali dilakukan penilaian oleh Pak Lurah perangkat desa yang memiliki kinerja terbaik.yang bersangkutan diberikan reward berupa uang sejumlah 600 ribu rupiah. Kemudian foto pamong tersebut dipasang diruang pelayanan.Untuk punishment ada pemotongan gaji bila tidak memenuhi jam kerja"(wawancara dengan Sunardiyono, S.Pd, Pangripto (Kaur Perencanaan) Desa Panggungharjo, 28 Juli 2021).

\section{d. Keterbukaan Informasi Publik}

Salah satu asas dalam menyelenggarakan Pemerintahan Desa menurut UndangUndang Nomor 6 Tahun 2016 tentang Desa adalah keterbukaan. Namun pada kenyataannya belum semua pemerintah desa menunjukan keterbukaan dalam penyelenggaran pemerintahan desa. Ketertutupan informasi dapat menjadi pintu masuk terjadinya tindak pidana korupsi. Hal tersebut menyebabkan masyarakat tidak dapat mengawasi proses penyelenggaraan pemerintahan desa maupun berpartisipasi dalam proses pengambilan kebijakan pembangunan (Suryani, 2019).

Sebagai bentuk pertanggungjawaban dan transparansi terhadap kegiatan penyelenggaraan pemerintahan desa termasuk penggunaan anggarannya maka pemerintah desa Panggungharjo menyampaikan informasi tersebut melalui website Desa Panggungharjo yakni http://www.panggungharjo.desa.id/. Pengelolaan informasi melalui website dan teknologi informasi lainnya di Desa Panggungarjo dilakukan oleh Pengelola Sistem Informasi Desa (PSID). Pengaturan terkait kerterbukaan informasi publik di Desa Panggungharjo diatur melalui Peraturan Lurah Nomor 7 Tahun 2020 tentang Standar Layanan Informasi Publik Kalurahan Panggungharjo.

Terkait dengan keterbukaan informasi ini, Wahyudi Anggoro Hadi berargumen: 
"Transparansi atau keterbukaan informasi yang dibangun di desa panggungharjo adalah upaya untuk memperoleh kepercayaan dari warga masyarakat, sehingga diharapkan masyarakat akan berpartisipasi dalam proses pembangunan desa. Karena syarat partipasi adalah adanya kepercayaan masyarakat. Itu sebabnya transparansi menjadi penting." (wawancara dengan Wahyudi Anggoro Hadi, Kepala Desa Panggungharjo, 14 Agustus 2021).

\section{e. Meningkatkaan Kualitas Sumber Daya Manusia (SDM) Perangkat Desa.}

Kinerja suatu organisasi tentu akan sangat ditentukan oleh kualitas SDM dalam organisasi tersebut tidak terkecuali di tingkat pemerintahan desa. Dengan demikian maka keberhasilan penyelenggaraan pemerintahan desa sangat ditentukan oleh kualitas SDM aparat pemerintah desa. Terlebih dengan hadirnya Undang-Undang tentang Desa, dimana desa diberikan kewenangan untuk mengatur urusan rumah tangganya sendiri yang disertai dengan pelimpahan dana yang cukup besar maka peningkatan kualitas perangkat desa adalah hal yang urgent. Sehingga kewenangan dan dana yang diamanahkan oleh UndangUndang Desa dapat didayagunakan sekaligus dapat dipertanggungjawabkan.

Untuk meningkatkan kualitas SDM perangkat desa Panggungharjo maka Pemerintah Desa Panggungharjo memberi kesempatan kepada perangkat desa yang pendidikannya SLTA untuk melanjutkan pendidikan ke Perguruan Tinggi yang didanai oleh Pemerintah Desa Panggungharjo. Sehingga sejak tahun 2016 terdapat sejumlah perangkat desa yang di tugaskan untuk belajar di STPMD “APMD” untuk menempuh gelar diploma. Hal tersebut disampaikan oleh M. Ali Yahya, SH, selaku Jogoboyo atau Kasi Pemerintahan Desa Panggungharjo:

"Pamong yang ingin meningkatkan keilmuannya dikuliahkan di STPMD "APMD" biaya dari pemerintah desa. Hingga saat ini ada 3 staf yang dikuliahkan sedangkan dukuh ada 4 orang. Yang pendidikan SMA dikuliahkan D3." (Wawancara dengan M. Ali Yahya, SH, selaku Jogoboyo (Kasi Pemerintahan), 27 Juli 2021).

\section{Kendala yang Dihadapi}

Dalam melakukan upaya reformasi birokrasi tentu terdapat kendala yang harus dihadapi. Demikian pula yang terjadi di Desa Panggungharjo. Kendala-kendala yang dihadapi dalam rangka melakukan reformasi birokrasi di Desa Panggungharjo yakni:

\section{a. Disiplin Kerja}

Sudah menjadi kebiasaan pada masa kepemimpinan sebelumnya, perangkat desa berangkat kantor pada siang hari dan pulang sebelum waktu yang seharusnya. "Kalau dulu jam 9 berangkat habis dhuhur sudah pulang sedangkan sekarang jam 8 sampai jam 4 
terkadang masih molor tergantung kesibukan yang ada di kantor." (Wawancara dengan M. Ali Yahya, SH, selaku Jogoboyo (Kasi Pemerintahan), 27 Juli 2021). Untuk menciptakan disiplin kerja bukanlah hal yang mudah, maka pada tahun 2016 diciptakanlah sistem penggajian berbasis kinerja dimana salah satu indikator kinerja perangkat kerja adalah pemenuhan jam kerja.

"Pada awal kepemimpinan pasti ada tantangan dan ketika tantangan sudah turun yang harus dilakukan adalah membangun sistem pengunci agar perubahan tidak mundur lagi. Pada awal kepemimpinan selama dua tahun saya berangkat jam 08.00 pulang jam 16.00. Berjalan dua tahun ada dua orang yang mengikuti maka kemudian diciptakanlah sistem pengunci yang memaksa perangkat desa yang lain untuk disiplin masuk kerja jam 08.00-16.00 agar tidak muncul kegundahan dari perangkat yang sudah berubah disiplin kerjanya. Maka pada tahun 2016 diciptakan sistem penggajian berbasis kinerja..yang berkinerja baik ya berhak mendapatkan pendapatan yang baik yang berkinerja buruk ya mendapat penghasilan yang buruk. Sehingga kita malakukan analisis jabatan, analisis beban kerja, pengukuran kinerja dan memberikan tambahan penghasilan berupa tunjangan kinerja. Sehingga antara dukuh yang satu dengan dukuh yang lain berbeda tergantung capain kinerjanya meskipun beban kerjanya sama. Termasuk memasukan faktor tingkat pendidikan jadi dukuh yang lulusan SMA berbeda dengan lulusan kuliah untuk mendorong meningkatkan kapasitas mereka." (wawancara dengan Wahyudi Anggoro Hadi, Kepala Desa Panggungharjo, 14 Agustus 2021).

\section{b. Pola Pikir Perangkat Desa}

Adanya pola pikir perangkat desa yang menjadikan mereka sebagai pihak yang harus dilayani juga merupakan kendala dalam melakukan reformasi birokrasi. Dalam pola pikir tersebut, birokrasi mengkonstuksikan dirinya sebagai pihak yang menguasai, sedangkan masyarakat dikontruksikan sebagai pihak yang dikuasai. Dengan demikan menyebabkan birokrasi menjadi semena-mena terhadap masyarakat yang seharusnya dilayani. Dalam konfigurasi tersebut, praktik penyelewengan oleh birokrasi menjadi hal yang sulit untuk dihindari. Penyelewengan tersebut kemudian dapat dimanfaatkan untuk kepentingan pejabat atau aparat birokrasi (Pamungkas dkk, 2019).

Menghadapi tantangan tersebut, Wahyudi Anggoro Hadi memberikan pemahaman bahwa bukan perangkat yang harus dilayani oleh masyarakat namun sebaliknya masyarakatlah yang harus dilayani oleh perangkat desa.

"Pak Lurah memberi pemahaman kepada perangkat bahwa hubungan antara pamong dan masyarakat..pamong memberikan pelayanan kepada masyarakat bila masyarakat ada kesulitan pamong membantu menyelesaikannya." (Wawancara dengan M. Ali Yahya, SH, selaku Jogoboyo (Kasi Pemerintahan), 27 Juli 2021). 


\section{c. Kebijakan Reformasi Birokrasi yang Belum Didukung Regulasi.}

Setiap kebijakan yang diambil oleh pemerintah desa harus dilandasi dengan regulasi sebagai dasar pemberlakuan kebijakan tersebut. Namun regulasi yang ada kadangkala belum mampu mewadahi seluruh kebijakan pemerintah desa, dalam hal ini terkait dengan reformasi birokrasi. Dalam konteks Pemerintah Desa Panggungharjo, regulasi yang dimaskud adalah regulasi yang mendasari pemberian tunjangan kinerja. Seperti yang sudah disampaikan sebelumnya bahwa tujuan pemberian tunjangan kinerja adalah untuk mengoptimalkan pelayanan terhadap masyarakat melalui meningkatkan disiplin, kinerja dan hasil kerja. Namun, ketika kebijakan pemberian tunjangan kinerja diterbitkan tahun 2016, regulasi yang menjadi dasar kebijakan tersebut belum diatur oleh pemerintah. Regulasi yang mengatur keuangan desa pada saat itu adalah Peraturan Menteri Dalam Negeri Nomor 113 Tahun 2014 tentang Pengelolaan Keuangan Desa. Akan tetapi dalam regulasi tersebut, menurut pandangan Pemerintah Panggungharjo, belum mengatur terkait pemberian tunjangan kinerja bagi kepala desa maupun perangkat desa. Oleh karena itu, Pemerintah Panggungharjo melakukan diskresi terhadap Peraturan Menteri Dalam Negeri Nomor 113 Tahun 2014 yang kemudian menerbitkan Peraturan Desa Panggungharjo Nomor 01 Tahun 2016 tentang Pemberian Tambahan Penghasilan Aparatur Pemerintah Desa.

Kebijakan reformasi birokrasi berikutnya yang belum memiliki dukungan regulasi yakni terkait Badan Pelaksana Jaring Pengaman Sosial (Bapel JPS). Kebijakan ini menurut Wahyudi Angggoro Hadi merupakan diskresi terhadap Undang-Undang Nomor 40 Tahun 2004 tentang Sistem Jaminan Sosial Nasional karena tidak ada regulasi turunan dari Undang-Undang tersebut yang melarang desa untuk membentuk suatu sistem jaminan sosial bagi warga masyarakat desa.

"Contoh diskresi adalah Bapel JPS dari Undang-Undang Sistem Jaminan Sosial Nasional. Bapel JPS Pangungharjo didirikan tahun 2013, landasan hukumnya hanya keputusan lurah desa. Konsideran yang digunakan hanya 2 yakni UUD 1945 pasal 34: fakir miskin dan anak terlantar dipelihara oleh negara.. dan UU SJSN bahwa kewajiban untuk pengembangan sistem jaminan sosial tersebut menjadi tanggungjawab pemerintah. Setelah itu tidak ada Peraturan Pemerintah, tidak ada Peraturan Menteri, tidak ada Peraturan Daerah yang melarang desa untuk membangun sistem jaminan sosial." (wawancara dengan Wahyudi Anggoro Hadi, Kepala Desa Panggungharjo, 14 Agustus 2021).

Terkait diskresi tersebut, merujuk pada pendapat Wahyudi Anggoro Hadi, merupakan kapasitas regulasi yang harus dimiliki oleh seorang pemimpin yakni 
kemampuan untuk memahami aturan sekaligus membuat aturan.

\section{Capaian Reformasi Birokrasi Desa Panggungharjo.}

\section{a. Meningkatnya Partisipasi Masyarakat dalam Proses Pembangunan.}

Seperti yang disampaikan sebelumnya bahwa Reformasi birokrasi di Panggungharjo bertujuan untuk mengembalikan rasa kepercayaan masyarakat terhadap pemerintah desa, sehingga pada gilirannya masyarakat mau berpartisipasi dalam proses pembangunan di Desa Panggungharjo. Hal disadari karena untuk membangun Desa Panggungharjo tidak mungkin hanya mengandalkan peran dari Pemerintah Desa sehingga peran masyarakat dalam proses pembangunan menjadi hal yang urgent.

Berdasarkan kajian yang dilakukan oleh Wuryantono dan Ruswahyuningsih (2017) didapatkan hasil bahwa semenjak Wahyudi Anggoro Hadi menjabat sebagai Kepala Desa tingkat partisipasi warga dalam proses pembangunan mengalami peningkatan hal ini dikarenakan: Pertama, adanya political will dari kepala desa untuk membuka ruang-ruang partisipasi melalaui lembaga-lembaga kemasyarakatan yang dibentuk di Desa Panggungharjo. Political will menjadi penting mengingat masyarakat telah lama tidak dilibatkan dalam proses pembangunan sehingga dirasa perlu upaya dari kepala desa untuk menumbuhkan daya kritis dan kreatif warga masyarakatnya. Kedua, adanya rasa saling percaya warga masyarakat kepada pemimpinnya. Disamping itu, adanya dukungan dana untuk mewujudkan usulan-usulan warga serta untuk biaya operasional lembaga kemasyarakatan. Hal-hal tersebut mendorong masyarakat untuk terlibat aktif dalam proses pembangunan baik dalam perencanaan, pelaksanaan maupun evaluasi pembangunan.

\section{b. Meningkatnya Kualitas Pelayanan Publik.}

Adanya reformasi birokrasi di Desa Panggungharjo dirasakan manfaatnya oleh warga masyarakat Desa Panggungharjo karena salah satu point penting dalam reformasi birokrasi di Desa Panggungharjo adalah mengubah relasi antara pemerintah desa dan warga masyarakat yang diimplementasikan dalam bentuk perluasan pelayanan publik tidak hanya sebatas pelayanan administrasi publik melainkan juga pelayanan terkait barang dan jasa publik. Dengan demikian maka permasalahan masyarakat, yang tidak hanya terkait pengurusan administrasi, dapat diatasi melalui berbagai kebijakan reformasi birokrasi misalnya permasalahan kesehatan dan pendidikan diatasi melaui progam Bapel JPS, permasalahan sampah diatasi melalui BUM Desa, serta konflik dimasyarakat yang biasa berkaitan dengan sengketa tanah di selesaikan melaui Lembaga Mediasi Desa. 
Selain itu, pembenahan pelayanan administrasi publik melalui Pelayanan Terpadu Satu Pintu menjadikan pelayanan administrasi menjadi lebih mudah serta cepat. Hal tersebut disampaikan oleh Sajuri, salah satu warga Desa panggungharjo yang bertempat tinggal RT 7, Glugo, yang mengurus surat pembagian harta waris sebagai berikut:

"Mengurus surat waris harta waktu yang dibutuhkan cuma 5 menit sudah mendapat tanda tangan Pak Lurah biasanya kalau mendapatkan tanda tangan Pak Lurah kan lama.." (wawancara dengan Sajuri, warga Desa Panggungharjo, 30 Juli 2021)

Hal yang sama disampaikan oleh Catur Hermawan warga RT 01, Geneng pada saat mengurus akte kelahiran anak, yang menyatakan bahwa pelayanan pengurusan administrasi di Desa Pangunghajo sudah berjalan dengan baik dan cepat. Demikian juga hal yang disampaikan oleh Agus Budi Santoso warga RT 06, Krapyak Kulon yang mengurus surat nikah menyatakan bahwa dengan adanya Pelayanan Terpadu Satu Pintu maka antrian untuk mendapatkan pelayanan tidak banyak. Dengan demikian pengurusan surat nikah dapat dilakukan dalam waktu yang singkat.

Dengan adanya perbaikan kinerja pemerintah desa melaui reformasi birokrasi maka keluhan terhadap penyelanggaraan pemerintah desa menjadi minim. "Keluhan dari masyarakat otomatis berkurang.

Hal-hal yang disampaikan dari masyarakat adalah hal-hal yang baik-baik karena mereka telah dilayani dengan baik. Ada kemajuan yang signifikan dalam pelayanan kepada masyarakat." (wawancara dengan Ari Suryanto, Ketua BPD Desa Panggungharjo, 30 Juli 2021).

\section{c. Penghargaan dari Berbagai Pihak.}

Adanya reformasi birokrasi tentu berdampak pada meningkatnya kinerja pemerintah desa Panggungharjo. Sehingga tidak mengherankan banyak Penghargaan yang diperoleh Desa Panggungharjo terkait kinerja pemerintah Desa Panggungharjo, baik dari dalam maupun luar negeri. Adapun beberapa penghargaan yang diterima oleh Pemerintah Desa Panggungharjo dari dalam negeri yakni Juara I Lomba Desa Tingkat Nasional 2014. Sedangkan dari luar negeri yakni Badan Usaha Milik Desa (BUMDes) Panggung Lestari Desa Panggungharjo menerima penghargaan The 4th ASEAN Rural Development and Poverty Eradication Leadership Award di Nay Pyi Taw, Myanmar.

\section{KESIMPULAN}

Reformasi birokrasi di tingkat pemerintah desa merupakan hal yang penting mengingat kinerja birokrasinya yang masih dianggap buruk. Penelitian reformasi Birokrasi di Desa Panggungharjo menunjukan bahwa kepemimpinan Kepala Desa 
Panggungharjo, Wahyudi Anggoro Hadi, memiliki peran yang besar dalam mendorong proses reformasi birokrasi di Desa Pangungharjo. Hal ini terlihat dari keteladanan maupun kebijakan reformasi birokrasi yang merupakan bagian dari tanggungjawab beliau selaku Kepala Pemerintahan Desa. Menjadi tanda tanya besar apakah reformasi birokrasi yang ada selama ini mampu dipertahankan ketika Wahyudi Anggoro Hadi tidak lagi menjabat sebagai kepala desa. Oleh karena itu, kaderisasi kepemimpinan di Desa Panggungharjo harus dapat berjalan dengan baik sehingga mampu menghadirkan sosok pemimpin yang memiliki kualitas yang setara atau lebih unggul dari Wahyudi Anggoro Hadi. Untuk mendapatkan calon pemimpin masa depan tersebut dapat dapat dilihat dari perangkat desa yang berkinerja baik maupun pimpinan lembaga-lembaga kemasyarakatan yang berkiprah dalam pembangunan di Desa Panggungharjo.

Agar reformasi birokrasi dapat dipertahankan maka kebijakan terkait reformasi birokrasi di Desa Panggungharjo harus memiliki payung hukum tertinggi di tingkat pemerintah desa yakni peraturan desa. Beberapa kebijakan terkait reformasi birokrasi seperti pembentukan Bapel JPS, saat ini pengaturannya hanya didasarkan pada keputusan lurah. Selain itu, terkait Keterbukaan Informasi Publik dan Pelayanan Administrasi Publik pengaturannya hanya didasarkan pada Peraturan Lurah. Sebaiknya, regulasi yang mengatur kebijakan reformasi birokrasi tersebut memiliki payung hukum yang lebih tinggi yakni peraturan desa agar memiliki kekuatan hukum yang lebih kuat.

Kebijakan reformasi birokrasi di Desa Panggungharjo juga dapat menjadi masukan bagi pihak-pihak yang menangani desa untuk membenahi kualitas birokrasi di desa-desa yang lain. Dengan demikian maka pelayanan kepada warga masyarakat desa dapat berjalan sesuai dengan harapan.

\section{DAFTAR PUSTAKA}

Albrow, Martin, 1989. Birokrasi. PT. Tiara Wacana, Yogyakarta.

Azhari. 2011. Mereformasi Birokrasi Publik Indonesia: Studi Perbandingan Intervensi Pejabat Politik Terhadap Pejabat Birokrasi Di Indonesia Dan Malaysia. Pustaka Belajar Offset, Yogyakarta.

Haning, Mohamad Thahir. 2015. Reformasi Birokrasi: Desain Organisasi Yang Mendukung Pelayanan Publik Di Indonesia. Ilmu Giri, Yogyakarta.

Hasyim, Djamil. 2016. Peranan Kepemimpinan Dalam Meningkatkan Kualitas Pelayanan Publik Pada Kampung Paray Distrik Biak Kota Kabupaten Biak Numfor. Jurnal "Gema Kampus" Ilmu Administrasi Edisi Vol. XI 
Kusmayadi, Edi dan Taufik Nurohman. 2011. Reformasi Birokrasi di Tingkat Desa (Studi Komparasi Pelaksanaan Reformasi Birokrasi dan Pelayanan Publik di Desa Sukakerta dan Desa Setiawangi Kecamatan Jatiwaras Kabupaten Tasikmalaya). Jurnal Aliansi Vol. 3 No. 2.

Mustafa, Delly, 2014. Birokrasi Pemerintahan: Edisi Revisi. Alfabeta, Bandung.

Pamungkas, W.S.B., Wibowo A.A.S, Yuniati, A. Reformasi Birokrasi Pada Administrasi Publik. Jurnal STIAMI. Vol. 2, No.1

Saefulrahman, Iyep. 2015. Kepemimpinan, Modal Sosial, Dan Pembangunan Desa (Kasus Keberhasilan Pembangunan Di Desa Pangauban Kecamatan Cisurupan Kabupaten Garut). Jurnal CosmoGov. Vol.1 No.1.

Sedarmayanti. 2013. Reformasi Administrasi Publik, Reformasi Birokrasi dan Kepemimpinan Masa Depan: Mewujudkan Pelayanan Prima dan Kepemerintahan Yang Baik. PT. Refika Aditama, Bandung.

Sinambela, Lijan Poltak, 2016. Reformasi Pelayanan Publik: Teori, Kebijakan, dan Implementasi. PT. Bumi Aksara, Jakarta.

Soemitro, Ronny Hanitijo. 1998. Metodologi Penelitian Hukum, Metode dan Jurimetri. Ghalia Indonesia, Jakarta.

Suryani, Dewi Amanatun. 2019. Peran Pemerintah Desa Panggungharjo Bantul dalam Mewujudkan Good Governance melalui Pengembangan Sistem Informasi Desa. Journal of Public Administration and Local Governance. Vol.3 (1)

Wuryantono, Theodorus dan Ruswahyuningsih. 2019. Masyarakat Berdesa: Realita atau Utopia? Penelitian Evaluasi Tentang Partisipasi Masyarakat Desa Pasca Implementasi Undang-Undang Desa. STPMD APMD Repository

\section{Website}

Novidwyanto, Kelik. Wahyudi Anggoro Hadi, Pemimpin Muda yang Lahir dari Desa. https://www.brilio.net/creator/wahyudi-anggoro-hadi-pemimpin-muda-yang-lahirdari-desa-b27349.html. Diakses pada tanggal 3 September 2021.

https://www.panggungharjo.desa.id/prestasi/ diakses pada tanggal 29 April 2021 pukul 19.37

https://www.panggungharjo.desa.id/BUM Desa/ diakses pada tanggal 29 Agustus 2021 pukul 09.24

\section{Peraturan Perundang-undangan}

Republik Indonesia. 2014. Undang-Undang Nomor 6 Tahun 2014 tentang Desa. Lembaran Negara Republik Indonesia Tahun 2014 Nomor 7.

Pemerintah Desa Panggungharjo. Peraturan Desa Nomor 01 Tahun 2016 tentang Pemberian Tambahan Penghasilan Aparatur Pemerintah Desa. Lembaran Desa 
Panggungharjo Tahun 2016 Nomor 1.

Pemerintah Kalurahan Panggungharjo. Peraturan Desa Nomor 4 Tahun 2021 tentang Tunjangan Kinerja Bagi Lurah, Pamong Kalurahan, Staf Kalurahan dan Badan Permusyawaratan Kalurahan Panggungharjo, Kapanewon Sewon, Kabupaten

Bantul. Lembaran Kalurahan Panggungharjo Tahun 2021 Nomor 4.

\section{Wawancara}

Wawancara dengan Perangkat Desa Panggungharjo, M. Ali Yahya, SH, 27 Juli 2021.

Wawancara dengan Perangkat Desa Panggungharjo, Sunardiyono, S.Pd, 28 Juli 2021.

Wawancara dengan warga Desa Panggungharjo, Catur Hermawan, 28 Juli 2021.

Wawancara dengan warga Desa Panggungharjo, Agus Budi Santoso, 28 Juli 2021.

Wawancara dengan warga Desa Panggungharjo, Sajuri, 30 Juli 2021.

Wawancara dengan BPD Desa Panggungharjo, Ari Suryanto, 30 Juli 2021.

Wawancara dengan Kepala Desa Panggungharjo, Wahyudi Anggoro Hadi, S.Farm, Apt., 14 Agustus 2021. 